\title{
External Political Actors and Influences in the South Caucasus
}

\author{
George Tarkhan Mouravi \\ Institute for Policy Studies, Georgia
}

Copyright $(2016$ by authors, all rights reserved. Authors agree that this article remains permanently open access under the terms of the Creative Commons Attribution License 4.0 international License.

\begin{abstract}
The paper focuses on the means and forms of external influence on political regimes and state policies, mainly considering the case of the former Soviet republics of the South Caucasus, with special focus on Georgia. This topic is particularly interesting due to the specific vulnerabilities of the region with regards to such multiple factors of external influence as: complex geopolitical environment - due to the location at the crossroads and peripheries of important geopolitical regions; totalitarian legacy as reflected in the weakness of institutions and the post-totalitarian political culture; ethno-territorial conflicts; undeveloped and imbalanced economy. The case of these republics is important, also, as an interesting example presenting a multitude of rather diverse forms of external influence, and secondly, because of the potential to have an impact on political events at much greater scale.
\end{abstract}

Keywords South Caucasus, Georgia, External Influence, Regional Political Actors, Regime Change

\section{General Remarks}

Attempts to impose a certain regime change on another state are nothing either new or uncommon. However, as spatial distances become increasingly irrelevant, nowadays it is not just neighboring states that try to influence developments in their neighborhoods but any interested external actor may try to impose some changes along the preferable lines, using whatever tools and leverages are at its disposal - military or economic strength ('hard power'), attractiveness of its model of governance ('soft power'), but also propaganda and various ideological, ethnic or religious instruments.

We will consider briefly the issue of external influence on formation, preservation and change of political regimes and state policies, as illustrated mainly by the cases of the post-Soviet republics of the South Caucasus, and more focus on Georgia. These may be particularly interesting both due to specific vulnerabilities, rising from a number of factors, such as: complex geopolitical environment, totalitarian legacy, ethno-territorial conflicts, weak economies; and, their location on the cross-roads and peripheries of various geopolitical regions; However, they are also important because they can be seen as a gate to the vast Eurasian space, represent the periphery of a number of important geopolitical and security regions, and influence political developments at much bigger scale.

It should be noted from the start that the concepts used throughout the text are far from being universally agreed on, neither are they easy to define. It is obvious that in the interconnected world that we live in borders are increasingly penetrable, cross-border information flows are difficult to control, and the channels of interaction between states and societies are numerous. One can argue that any of such interaction may have at least some kind of influence either on the state institutions, economies and policies either directly, or indirectly, by influencing the minds of the populations living within the given state. We can also say that many of these influences may be accidental by-products of some other processes, while in other more interesting cases the imposed changes are taking place through deliberate external actions, although even more frequently such actions may lead to rather unexpected and undesired outcomes, and as a number of scholars have noted, seldom such imposed change leads to democracy[1], even if post-WW2 Germany or Japan represent spectacular though very special exceptions, along with very few others.

It is equally difficult to outline the range of changes that we would like to cover, as they can take place in so many different ways and to a broad range of degrees, and, as so frequent in political science, it is not easy to precisely define what influencing regime/policy change would mean in our context. In many cases it is more subtle regime or policy change and political developments that are influenced by external actors in parallel with some other domestic factors, or even when radical changes take place such as in the case of 'color revolutions' that took place in the post-Soviet space it is difficult to unambiguously single out external factors from the complex combination of other 
factors leading to change. Regime change itself may imply the replacement of leadership with or without any essential institutional change, or another way around.

Fortunately, it is not the typology of change that interests us here but rather the channels and leverages used by external actors to induce such change, and we focus mainly on deliberate action aimed at achieving such changes. Still, it may make sense to distinguish several modes of external influence on regime/policy change in a state that may be used at the different stages of political development:

- Supporting/disrupting the sustainability of the existing regime through assistance/ sanctions and sabotage;

- Diffusion of norms, influencing the attitudes, values and skills of the population at large or some its segments through educational programs, programmatic support, mass media and communication channels;

- Inducing and promoting gradual change of a regime or policy, through (promise of) support or integration based on conditionality, or threats of withdrawal of such support, or using incentive-based pressures or rewards to influence elite regime preferences;

- Promoting a certain normative model for change through its advocacy and education;

- $\quad$ Supporting one of the sides during the ongoing competition for regime change or in policy debate, or influencing the procedure of the decision-making;

- Imposing regime change by force, including the regime change on a part of the territory (supporting conflict, annexation, open or covert military or terrorist action)

Among the key country-specific factors that influence both the formation and functioning of regimes, decision-making on policies, and susceptibility of political developments to various external influences, one may list: geography and geopolitical environment; economic and resource wealth; recent political history and establishment; general political culture, ethnic and religious make-up of the population; existence of conflicts and potential for instability; political elites opposing or promoting certain changes. There may also be some additional factors, such as e.g. the existence of influential diaspora in the case of Armenia or Israel, among other countries with big Diasporas.

What would determine the success or failure of the efforts to induce change? The relationship between international and domestic politics may play out differently in different states - some may comply with external pressures for ideological reasons, or primarily to attain material benefits. Authoritarian governments in the post-Soviet space [2] or the Middle East [3] tend to demonstrate strong resistance to regime change and have often successfully blunted both popular and international pressures for democratic consolidation and reform. Indeed, one needs to understand how many international factors interact with domestic conditions in order to explain the persistence and recycling of authoritarianism throughout the region, against the background of the surprising overthrow of long-running authoritarian regimes in the recent wave of political transitions in North Africa and some other regions.

Another interesting area refers to the channels of influence through which several powerful actors active in the region of the South Caucasus (Russia, USA, and EU, and less universally - Turkey and Iran) try to affect local political developments. In fact, quite a number of approaches (economic leverages, cultural exchanges, military threats and assistance, bribing elites, manipulating of minorities, ethnic diasporas, regional conflicts and political oppositions, propaganda, influencing international public opinion, citizenship and visa policies, border and territorial policies, pressures/prospects of joining various blocs and unions, legal or illegal arms trade, various embargoes and other sanctions, conditionalities, direct military action...) are applied in order to exercise influence. Various agencies and institutions, as well as some proxy actors (international and intergovernmental organizations, satellite or client countries or territories, mediating bodies and negotiation formats...) play equally important role in this process.

It is quite instructive to observe what factors would determine as to which of these channels of influence would be used by various external actors in order to achieve their goals - as that would depend on the level of importance ascribed to an issue and to the state in question, the level of respect of international and domestic law, international support to potential actions, resources available, and last but not least - institutional tradition and inertia, - and what is the nature of these goals. To some extent the explicit interpretation of national interests by ruling elites would determine such goals, while these interpretation in their turn would on one hand depend on ideological paradigms and conceptual frameworks (whether realist or idealist), while their formulation may also depend on the state of democracy and internal politics within respective states. It is also obvious that promoting authoritarianism differ from promoting democracy, to great extent because the promoters and therefore their approaches strongly differ.

Some of the above-mentioned factors tend to change with the change of leadership, as happened when in the US democratic president Obama replaced republican George W. Bush, but in other cases the same leadership may undergo dramatic changes in ideology and approach which it puts forwards publicly. So, we currently observe in case of Russia under Vladimir Putin as the new ideological paradigms come to dominance after several years of more pro-Western political discourse, such as: prioritizing Russia's responsibility over ethnic Russians and Russian-speakers ("Russkiy mir") outside Russia and "gathering of the Russian lands"; accentuated return to Russian religious orthodoxy and traditional values (e.g. 
homophobia) as opposed to the "moral degradation" of the West; returning to Russia of the status of the global player ("getting off the knees") and trying to weaken/opposing the global dominance of the USA, which tries ever to destabilize and humiliate Russia; asserting the idea of the "special path" of Russia, rooted in the ideas of Eurasianism; "correcting the injustice" of the last decades that Russia has experienced, with the encroachment of NATO and EU; promoting the idea of Russia's special interests and rights in its "near abroad, i.e. post-Soviet space[4]. This impressive list is important as during the recent years there have been consistent efforts by Russia to promote not just pro-Russian policies but also its own model of 'hybrid' authoritarianism in its 'near abroad' - when surrounded by autocratic regimes, there is little risk of importing any 'color revolution', but also such states are more easily manipulated, and they serve as a useful buffer dividing Russia from democratic Europe [5].

Approaches to inducing change of the major actors are also different indeed [6] and vary everywhere but in particular in the case of different South Caucasus states. They may also change in time.

For instance, Russia would mainly rely on military threats and stirring conflict as in case of Georgia, applying also economic sanctions and other 'negative' leverages, while in case of Armenia its approach will be more mixed, and including military and financial assistance but also taking over its main economic assets and energy infrastructure, and blackmailing it with withdrawing its support against Azerbaijan and Turkey. Russia's latest actions in Ukraine and now Syria demonstrate the increasing ruthless and often irrational (from the perspective of long-term national interests) actions when getting involved in internal conflicts of other nations, partly to use these as proxies to influence the policies of third parties (US and EU member-states).

The EU, in its turn, relies mostly on soft power attractiveness of its governance model and norms, hope of ascension, assistance provided, trade privileges, visa facilitation, mediation in conflicts, observer mission, and conditionality of assistance or integration. While this approach is highly effective in the situation of overall stability, it is less adequate in the cases when they need to act in the situation of emergency, or to counteract the actions defying international law and expected norms of behavior.

The USA also commonly provide significant economic aid, but at the same time would not shy away from providing military assistance, and would support more integration into NATO, as in the case of Georgia, or Ukraine. In case of recent conflicts in the Middle East, Washington is ready to get involved militarily as well, though currently to a rather limited degree; however, this may get replaced by more decisive approaches after the forthcoming presidential elections.

The Western soft power is especially attractive to the liberal intelligentsia in all three countries, however, the attractiveness of respective models and regimes are much more modest among other parts of the populations, more susceptible toward nationalist, traditionalist or fundamentalist populism that may see Western influence in much less favorable light. Especially interesting are the normative aspects of soft power applied by the West, in particular the own models of governance that these actors would support/promote in the South Caucasus. Both USA and EU try to promote democracy and the rule of law, although the normative models of development and social welfare are different, as are attitudes toward such issues as legitimacy of political lobbying or plea bargaining. On the other hand, Russia's normative offer is less attractive to liberals: "sovereign democracy", suppression of freedoms, omnipresent corruption, authoritarianism, and domination of the Russian language, culture and interpretation of history. That is why Russia has to rely more on hard power and negative leverages, which can be quite effective in the short term, but seem destined to fail in the longer run.

It might be intellectually and practically meaningful to design some methodology to stress-test the capacity of states and political systems to withstand undesirable, dangerous and destructive influences, determining the ability of a state to deal with various types of such influences and manipulations, looking at how robust the political system is in different critical situations, in a form of scenario analysis. They may test the political system under, for example, the following stresses:

- What happens if an external actor tries to kindle a potential ethno-territorial or other conflict, or attempts to organize hybrid warfare?

- What happens if through external financial support or active propaganda some internal political forces may come to power, endangering the state's sovereignty, or changing its external orientation?

- What happens if external economic sanctions are imposed, and the national economy is close to collapse?

- What happens if there is an external attempt to bribe, to blackmail or otherwise control key state officials in order to change governmental policies?

While we are not at present undertaking such a stress-test in the case of the three South Caucasian states, the text below will describe the political contexts and developments there keeping these questions in mind, while leaving more consistent and formalized stress-testing as an exciting challenge for the future.

\section{The South Caucasus Context}

The three states of the South Caucasus, this small area on the periphery of both Europe and Asia, have moved during the last two and a half decades since the collapse of the Soviet Union along strikingly different political trajectories, whether from the viewpoint of internal developments or of 
external orientations. Respectively, these different trajectories depended mainly upon the internal (ethnic, religious, cultural, linguistic, and those related to political tradition) differences and geographic location, but also on the external influences that in their turn would depend on the above-mentioned differences in which policies and approaches are applied by external actors, and what impacts are produced.

Of course, the specificities of political history of the South Caucasian states have had a direct influence on how modern political landscape developed, although some aspects of the situation may be essentially not too different from other post-Communist transitional societies, particularly in the post-Soviet south, and there are some general similarities among all the political regimes in this bigger region. Although in post-Soviet times the political paths of the states' diverge, some transitional patterns remain quite similar. The task here is to understand, what is common and what is different between the societies of the South Caucasus region, and how much of these differences, and changes in general, are externally influenced, or in their turn influence the policies of external actors?

After the dissolution of the Soviet Union and the emergence of newly independent South Caucasus states, governments have shown the willingness, sometimes under external pressure from much-needed donors, to break with the Soviet legacy in the area of governance and carry out reforms in public management, even though the process got hindered by ethno-territorial conflicts and civil turmoil of early 1990s. In the South Caucasus, the heritage of the Soviet past in the form of underdeveloped democratic institutions and political culture, along with the scars caused by authoritarian suppression, civil wars and ethno-territorial conflicts, haunted political processes and civil society building, narrowing the space for political and social discourse, and led to what now is commonly called 'competitive authoritarianism'[7] of 'hybrid regimes' (to use the term introduced by Terry Lynn Karl back in 1995). Such hybrid regimes combine a high degree of state centralization with the stripping formally democratic institutions of real content, and their methodical replacement with substitutions that are intended to serve some of their functions but without challenging the incumbent leaderships' hold on power [8].

There are also other commonalities, and indeed the states that had emerged from the Soviet breakup were initially very similar in many respects, and they underwent equally painful withdrawal from the Soviet relations between the state and the private segments of economy, the same system of paternalistic social welfare, and state control over many aspects of life. The Russian language continues to serve as lingua franca throughout the region (even if in some segments of the societies replaced gradually by English, especially in Georgia). Many specialists, particularly of older generations, had been trained in similar professional and intellectual traditions, and national bureaucracies were accustomed to working in similar ways.
In a paradoxical and maybe even ironic sense, Francis Fukuyama's concept of the 'end of history' found all over the post-Soviet South Caucasus a spectacular if somewhat ironic illustration - while the advent of Western-style liberal democracy was still a remote possibility, all these governments have learned to imitate[9], although with different skills, the formal aspects of democratic institutions, and the leaders just love to talk about democracy and the rule of law, most probably interpreting these in their own surreptitious way. Such imitational democracy is to some extent rooted in the old Soviet tradition of organizing fake elections with single candidates and no competition, but also no real power wielded by elected officials, even if similar pattern can be easily discovered far beyond the post-Soviet space. As a result, often imitations replace real democratic institutions, these becoming empty façades without any real democratic content.

However, it is not just democracy that was imitated in these countries. Another imitation was that of the free market, as while the legislations might be quite liberal, property rights were not well protected, there would be no independent judiciary to seek justice against the state (or persons close to the government), the biggest businesses were owned by those with connections within the ruling elite, and little was done to support small and medium businesses. On the surface, all the countries embraced economic freedom and private initiative, and everywhere, although to different degrees, one could observe on one hand the capture of business by state bureaucracy (or sometimes another way around), on the other, informal mechanisms for controlling businesses. This was accompanied by total defenselessness of labor, due to lack of any effective trade-unions, increasing gap between the poor and the rich, and the high-level corruption permeating all big-scale business transactions. As a result, even when economy was growing, the poor still remained numerous, while the gap between the rich and the poor was growing rapidly. In most cases this would lead to massive labor migration, and for the poor countries of the region, remittances from economic migrants still make a significant share of GDP.

After achieving independence, it was the new elites that came to power in all three South Caucasus states that had to lead the systemic redesign of the government, although to great extent they lacked respective skills, and had to work in the critical conditions of economic crunches and ethno-territorial conflicts. It is not surprising then that on one hand these first generation governments, focused on ethno-national mobilization, were not too efficient in bringing order to their respective states, and on the other were soon replaced through rather unconstitutional means, and at least in cases of Georgia and Azerbaijan bringing back former Communist leaders back to power (in case of Armenia, the second president Robert Kocharyan that came to power after the first - Levon Ter-Petrossian - ousted in February 1998, had a much more modest communist party record than Eduard Shevardnadze and Geydar Aliev, having 
served just as a Communist party leader of a silk factory in Stepanakert, Mountainous Karabakh), although distancing themselves from the Communist ideology.

Respectively, one of the interesting political aspects of the region is the similar system of governance adopted by these countries. All the leaderships were putting state-building and centralization of power first, while considering the consolidation of democracy as a more peripheral goal. This led to certain neglect of human rights, to lack of political pluralism and attempts to marginalize opposition, weakening of already fragile system of checks and balances and local self-governments, to consolidation of state control over electronic media, and growing mutual mistrust between the government and the people. One may speak of 'post-Soviet governance contagion' (in a distant analogy with the Arab spring, or rather reminding us of so called 'Galton's problem')[10], when elites borrow from one another various models and approaches, especially related to the way to strengthen power of the ruling party and weaken opposition, but also in terms of institutional arrangements. This in the first place refers to the presidential model as a universal one in all of post-Soviet states, even though some of these at initial stage may have tried parliamentary model as well. Only Georgia has recently, after the change of regime in October 2012, moved to a more mixed model with relatively stronger prime-minister's post.

Another common characteristic feature is the dominance of the executive branch of power over other branches, obedient parliaments, and the particular weakness of the subservient judiciary system, which to great extent serves and legitimizes decisions made by the executive. The parliaments are commonly dominated by the executive and used as a symbolic agency for rubber-stamping the decisions parachuted from above. Political arena is universally controlled by the parties or coalitions controlled by respective presidents (with the specific exclusion of Georgia, where former prime-minister Bidzina Ivanishvili seems to have retained strong informal influence, while the president is deprived of any real power despite his popularity), and are ready to use administrative resource and populism to win elections.

Nevertheless, the status of democratic reform is not the same in the three states. These differences are represented in a range of substantive policy categories including: human and civil rights, treatment of dissidents and opposition, rule of law, tolerance for religious and ethnic, the character of the business environment, fight against corruption, or geopolitical orientation. While Georgia has moved forward to an extent, in other two states of the region weak and ineffective opposition is as a rule unable to create any viable alternative to incumbent elites, and any dangerous challenge would normally emerge due to splitting of the former allies in power, or from the spontaneously organized grass-roots social movements. The same ruling elite attempts, and to varying extent succeeds to control mass media, and in particular electronic media. Neglect for human rights, and frequent human rights abuse by law enforcement, readiness to use excessive force against opposition and mass protests are still other specific characteristics of the post-Soviet political reality in the these states. Indeed, other than in the case of Georgia, which tend to demonstrate more political volatility, as well as more democratic freedoms, the same political regimes rule for many years, and everywhere there is the same problem of succession - and while the same clan would retain power, the transition itself was somewhat differently resolved - in the case of Azerbaijan (from father to son), in Armenia (from president to prime-minister).

Along with similarities, some key differences are important to note. The three countries in question differ not just by size (e.g. Azerbaijan is almost 3 times bigger and more populous than Armenia, although it should be mentioned that Baku has currently no control over a significant chunk of its territory), but also by population density (105-106 population per sq. km in Armenia and Azerbaijan vs. only 62 in more mountainous Georgia), and even more importantly - birth rate (17 in Azerbaijan vs. 14 Armenia and Georgia). Another interesting point is looking at the economic profile of the three states, and in particular at the role of energy resources in their economy: The littoral state of the Caspian Sea - Azerbaijan, is rich in oil and gas, while other two states are strongly dependent on the energy imports and in some cases on the transit of energy resources (Georgia, though, is relatively rich in hydropower potential, while landlocked Armenia do not possess any significant amount of fossil energy resources, but also do not play any significant role as an energy transit country). Size and economy are important characteristics, but still there are several issues to look at, such as e.g. confessional and cultural tradition. Georgia is predominantly Eastern Orthodox, while Armenia - 'Gregorian' Christian, while in Azerbaijan Shiya Islam is the dominant confession (however, about one third of the Azerbaijan's population is reportedly Sunni, and Azerbaijan since Soviet times is also basically a secular state, although the influence of Islam seems to be growing).

\section{Country Cases, with Special Focus on Georgia}

Having discussed the similarities and differences between the three South Caucasus states, it is worth considering a few examples of external influence on regime/policy change in each of these.

\subsection{Georgia Case}

Georgia used to be often seen just as a part of the Soviet/Russian political or cultural sphere while of little if any importance for Europe, while there was little understanding of rather complex regional context in which the country existed. Still, one should not dismiss Georgia's 
achievements in building imperfect but functional democratic institutions, fighting corruption, and resilience of its population in securing legitimate democratic procedures for electing of its government. Notwithstanding difficulties and hurdles, and rather imperfect political transition, Georgia is currently seen as a front-runner within the post-Soviet space in terms of democratic and economic freedoms, pro-western orientation and stable governance. At the same time, Georgia's path toward European and Euro-Atlantic integration is impeded, the Russian threat of hybrid or direct action is looming, and ethno-territorial conflicts in Abkhazia and South Ossetia provinces occupied by Russia remain unresolved, while Georgia finds itself in increasingly unstable geopolitical environment and vis-à-vis the loss of interest and engagement from its western partners. While Georgia's future is still burdened with uncertainties there is still enough ground for optimism, although indeed - Europe and the West still can and should do more to help Georgia to stay on its promising path.

For centuries Georgia had difficulty surviving as a state, a continuous battlefield for its more powerful neighbors, until it was finally annexed by Russia in early 19th c. and since constituted the southern flank of the Russian Empire and then the USSR. With the dissolution of the Soviet Union Georgia became known in the West due to its strategic location on the crossroads between Europe and Asia but also due to the bloody conflicts of early 1990s that took place either within Georgia (in Abkhazia and South Ossetia) or close to its borders (Mountainous Karabakh, North Ossetia-Ingushetia, Chechnya). The existence of two breakaway territories of Abkhazia and South Ossetia that have been de-facto annexed by Russia and formally recognized by it after the Russian-Georgian war of August 2008, where Russian military bases are located within a few dozen kilometers from the Georgia's capital, Tbilisi, has impeded the country's economic and democratic development, and prevented its closer integration into European and Euro-Atlantic strictures.

History not only determined geographic boundaries and unique multi-ethnic demography of the country, but it has also brought around such facts as Russian military presence on the Georgia's soil. Georgia's historic path and in particular the Soviet legacy have influenced political culture and social skills of the population and its attitudes toward private property and business, the role of the state as well as the weakness of political and social institutions, and underdevelopment of political and entrepreneurial classes.[11]

After achieving independence in early 1990s, there was a lot of initial sympathy in the West toward the regime of Eduard Shevardnadze, who gradually came to power during 1992-1994 and greatly contributed to its stabilization, even when he was no more able to control surging corruption and power abuse, still relying on the already outdated but also waning skills of extraordinary Soviet apparatchik. Experienced pragmatist, he was also a master of imitation of requested political changes, although much what was happening under the aegis (or disguise) of market liberalization, new public management, and democratization, promoted by international organizations and western donors, was more of a façade. Still, the western partners and donors were slow to take serious notice of such developments, though the paradox has been observed by a number of experts. So, Charles King would call democracy built under Shevardnadze "Potemkin democracy", hinting to the story of fake villages created to impress Russian Empress Catherine II by her powerful favorite[12]. Almost a decade later, Shevardnadze would call the then incumbent president, his replacement Michael Saakashvili, and the favorite of many Western politicians from center-right parties, a "questionable democrat" at best, and asking whether Saakashvili's governing style related more to the state of democracy in Georgia than to that of Russia, and agreeing with another renowned author, Lincoln Mitchell, who labeled Georgia's democracy as 'uncertain'[13] Saakashvili came to power due to public displeasure with the rule of aging Shevardnadze that was to soon resign, but external influence in preparing and securing the peaceful transition was very significant, including training and support provided to opposition forces by western organizations, pressure on the incumbent Shevardnadze's government not to resort to violence in order to suppress opposition, the "CNN effect" of international media coverage expertly exploited by Saakashvili, and finally Russian mediation of Shevardnadze's resignation. Nevertheless, same Mitchell would write: "For most of the time since Georgia's Rose Revolution in 2003, concerns about the increasingly less democratic nature of Georgia's regime, which people in Washington began to notice sometime around 2008, were always raised privately. A trip to Tbilisi by a visiting U.S. official would include public congratulations to the Georgian government for its democratic credentials, while concerns about the lack of media freedom, recent electoral or legal shenanigans, or the growing centralization of political power were made privately and discreetly. Similarly, Georgian officials visiting Washington were publicly greeted with platitudes about the strength of Georgian democracy, while concerns were, again, raised privately."[14]

Nevertheless, the western influence played a crucial role in regime change, when Saakashvili's party eventually lost elections in October 2011, and he was persuaded through persistent efforts of western politicians to accept the failure to control the new parliament. However, the same Western politicians and analysts that would advise Saakashvili to improve relations with Russia, and would shut eyes to many cases of human rights abuse and selective justice by his government, would harshly criticize the new government when it in its turn attempted to mend relations with Russia, or make some of the same mistakes that were readily tolerated when committed by the Saakashvili's government (e.g., restricting media freedom, or violating judicial procedures). 
While there was some disappointment toward the west when the political support provided during the war with Russia of August 2008 was deemed inadequate, Georgian government and society remain in strong favor of Euro-Atlantic integration, and Georgia was eager to initialize the Association Agreement with EU in November 2013 (signed in June 2014). The West did not push forward any agenda of radical regime change in Georgia, but instead would support democratic reform, human rights, rule of law and economic reform through financial support, training, educational programs, advice and know how, informal pressures, but also through support on international arena, and assisting to promote its security (EU by its monitoring mission - EUMM, US - through limited military support). This has not essentially changed since the very first years of Georgia's independence, although such support has experienced ups and downs although generally shows increased involvement.

Russia's approach has been very different from the very beginning. Russia played a role in the downfall of Gamsakhurdia's rule, it supported secessionist entities in Abkhazia and South Ossetia after finally recognizing their independence after the 2008 war, but also at certain periods supported ethnic unrest in other regions; it mediated the change of leadership in Georgia in 2003, and in its autonomy of Ajara in 2004; it used military action against Georgia on several occasions, overtly or covertly, and in August 2008 openly claimed its goal to forcibly change Saakashvili's regime in Georgia; it keeps military bases and forces in the internationally recognized Georgian territories of Abkhazia and South Ossetia; it threatened unspecified action if Georgia joins NATO, and some government funded centers (e.g. RISI[15]) publicize Russia's interest in fragmenting Georgia and causing turmoil there[16] it has used economic sanctions such as embargo on Georgian imports, and used selective mass deportations of ethnic Georgians from Russia when dissatisfied with Georgian pro-western policies; finally, it supported political parties or other institutions that would show anti-Western, pro-Russian orientation and attitudes. One of the factors of anti-western resistance became the Georgian Orthodox Church, as some of its representatives, in close relationship with its Russian counterpart use its significant influence in the Georgian society in order to promote 'traditional family values', homophobia and religious intolerance.

\subsection{Key Factors Influencing Developments in Georgia}

In order to get a somewhat structured picture of contemporary Georgia within its geopolitical context, several major factors or areas that influence the developments in the country could be singled out:

After two and a half volatile decades of independence, and a number of changes of political leaderships, many of the weaknesses of early post-Soviet political institutions still remain and hinder Georgia's development. Key political institutions remain weak in the system dominated by the executive branch of governance where the president notwithstanding significant power provided by the constitution remains a symbolic token, while many decisions are made through behind the scene processes dominated by the powerful figure of the former prime-minister and tycoon Bidzina Ivanishvili. While certain steps were undertaken to strengthen the judiciary and streamline the whole system of law enforcement, investigation and courts, there is still much to be done along this key direction leading to the rule of law. While relative political stability is a good thing for consolidating democracy, some other tendencies do not favor the development of truly democratic political culture and elites. While the government has demonstrated its relative consistency in pursuing pro-western and democratic path, it still demonstrates a multitude of weaknesses that hinder progress. The biggest problem seem to be the personnel policy pursued when forming the government, as many of the ministers seem to lack vision, independence, initiative and courage, while the key decisions seem to be made by the very small group of leaders and in rather closed manner, and there are strong suspicions that the former prime-minister Ivanishvili still pulls the strings behind the scene. As a result, the government while dominating the decision-making process, is often unable to demonstrate consistent strategic approach, consolidated vision of what and how should be done, and the ability to avoid decisions and rhetoric that damage the democratic credibility of the ruling elite.

Unresolved conflicts in Abkhazia and South Ossetia for the last two and a half decades remains one of the most troubling and sensitive issues for the Georgian people, even if sometimes its seems to be overshadowed by more immediate concerns over deteriorating economic conditions or security threats emanating from Russia. Especially painful issues are relate to the existence of about 250.000 IDPs from the two regions unable to return to their homes, and the dire situation of those ethnic Georgians who still continue to live in Abkhazia and South Ossetia under conditions of discrimination and repression. Over the last many years each of the parties to the conflicts have made numerous mistakes, and Georgia is paying a high price for its own errors. There seems no scenario for the conflicts to be resolved any time soon, especially after Russia has recognised the sovereignty of the two territories in the aftermath of the 2008 war, and stationed there its own military bases. Russia's hold on the region has further strengthened even formally after the two entities signed treaties with Russia in 2014-2015 actually integrating into Russian military, law enforcement and economic space, while formally retaining 'independence'. On the one hand, Russia refuses to acknowledge itself as a party to the conflicts and regularly calls on Tbilisi to negotiate directly with Tskhinvali and Sukhumi. On the other hand, Russia has sought to retain full control over any dialogue and exclude any 'overseas partners' as mediators. Russia's approach implies that a resolution to the conflicts is 
hypothetically possible but at a price too high for Georgia to seriously consider. Russia may want Georgia's membership in the Eurasian Economic Union in return, an option unacceptable to Tbilisi.

As the key problem of Georgia is its permanent sense of insecurity vis-à-vis its northern neighbor - Russia, it is no surprise that the regional dimension largely defines political as well as economic situation Georgia. Although currently here is little probability of direct invasion from Russia (as it happened in August 2008) in the immediate future, this risk should never be neglected as the regional tensions rise, especially between Russia and the Georgia's Southern neighbor - Turkey. Another security threat emanating from Russia is related to the possibility of aggravated hostilities in the Russia's North Caucasus, the spill-over of conflict, terrorism and militants to Georgia, or Russian military action on Georgian territory against the North Caucasian militants (aerial attacks have taken place in mid-2000s). In particular, there are risks related to the future return of hardened Salafi fighters from the Middle East bringing along the risks of terrorism and instability, but also their presence could serve as casus belli for Russian military action. To sum up, Russia remains the only existential threat to Georgia's security and sovereignty, with its leadership following the confrontational path toward the West, applying dangerous skills of hybrid operations, aggressive propaganda and deceit, and economic pressures but not shying away from more direct military threats or actions with the full disregard of international norms, agreements and obligations whenever this is deemed useful for spreading the atmosphere of fear and control, and on the other hand, for rather irrationally trying to hurt the West through proxies and divisive policies, countering any possibility for increased western influence, democratization or Europeanization of Russia's neighbors such as Georgia. In the end, notwithstanding impressive support from Georgia's Western partners and supporters - the EU and US in the first place, in the end there are no safeguards for Georgia against Russian possible aggression, and nobody is ready to risk directly opposing Russia's actions on behalf of a country not protected by the Article 5 of the North Atlantic Treaty (as is currently demonstrated in Ukraine).

As the Georgian economy is strongly linked with the Russian economic system, mainly through bilateral trade and remittances, financial problems and the trouble devaluation there had a serious impact on Georgia as well. Foreign trade turnover fell by $12 \%$, imports declined by $9 \%$, and exports declined by $23 \%$, as the trade deficit is also growing. During the winter of 2015-2016, the Georgian currency GEL approached its all-time low, having lost almost $40 \%$ of its value since September 2015. It is hence no surprise that according to the recent NDI (National Democratic Institute) poll, economic and social issues, and high unemployment in particular, are at the top of people's concerns for the first time, while earlier political issues such as restoring territorial integrity dominated.

This is coupled with the general increase of the widespread feeling of uncertainty of the future that may be laden by dangers, poverty and instability. This is further aggravated by geopolitical unpredictability caused by the new assertiveness of neighbouring Russia that gets since invading Georgia during the brief Russian-Georgian war of August 2008, and the annexation of Crimea in the spring of 2014, gets involved in one military adventure after another (Ukrainian Donbas, Syria), ready to opportunistically ignore international law or own agreements whenever deemed profitable by the small circle of autocratic leadership, if not just a single person. To some extent the actions of Georgia's southern neighbor - Turkey - also follows a somewhat unpredictable path both in internal affairs and external actions. At the same time, now in the light of Russia's actions in Ukraine the West is taking Russian transgressions much more seriously.

The big southern neighbor, Turkey, has maintained good relations with Georgia, being one of its main trade partners and sources of investment, a part of collaborating on a number of transportation projects such as oil and gas pipelines, and Baku-Tbilisi-Kars railway. At the same time, before the drastic deterioration of Russian-Turkish relation in spring 2016, Turkey was careful not to spoil relations with Russia while pursuing common interests, such as deterring the presence of external military capacities in the Black Sea, or cooperating transporting energy resources to Europe. As Georgia is sandwiched between Russia and Turkey, any further worsening of the latter two country's bilateral relations generates security threat for Georgia, as it divides Russia from its important military base in Armenian Gyumri.

Georgia's relations with his other immediate neighbours is stable and friendly, even while e.g. Armenia is hosting a Russian military base, and joined the EAEU bloc as an alternative to the European integration process. Armenia, Azerbaijan and Georgia have radically divergent aspirations, external orientations, levels of political and economic developments and different political destinies. While Armenia is Russia's 'strategic partner' and CSTO member, Azerbaijan is more reluctant to join any formal alliance. However, it is difficult to predict future alliances in the region that may strongly depend on how the Karabakh conflict unfolds, the issue strongly manipulated by Russia. If Karabakh conflict turns into an open war, once again Georgia may get endangered on several fronts, whether due to the existence of big Armenian and Azeri minorities living side by side in Georgia and the possible spill-over of hostilities, the risk of mass inflow of refugees, or Russia's involvement in the conflict.

As Georgia is a small country, it is not surprising that the international context is of special importance for its developments. There has been obvious progress in Georgia's course towards further Western integration, and it is widely expected that Georgian citizens will finally receive the long promised visa-free regime with the EU during 2016, in accordance with the EU AA. However, Georgia suffers due to the lack of strategic vision of its 
government, weak rule of law, and the lack of pro-active diplomacy - as the Georgian current leadership appeared unable to gain full support of its the western partners who had doubts on domestic political situation, selective justice and general level of democracy.

Over the years, humanitarian, technical and development assistance from the European Union and the United States helped Georgia to survive in the most difficult times. EU played a key role in stopping the military action during the Russian-Georgian war of 2008, and the EU Monitoring Mission (EUMM) plays an important role in securing piece since. At the same time, Brussels was always careful not to antagonize Russia by supporting Georgia's aspirations to join NATO or integrate into the EU, providing political support over sensitive issues, or any direct military assistance. Now with the major headache linked to looming Brexit after the referendum held, there is even less opportunity (and resources) that the EU will be dramatically increasing political support for Georgia.

The US went further in assisting Georgia beyond purely technical and financial aid, however appeared unable to persuade some of its European partners not to block Georgia's Euro-Atlantic integration, its key hope for achieving security. At the same time, Georgia's pro-western orientation and close relations with its western supporters has always been also a risk factor, as Russia never hesitated to threaten to react to Georgia's aspirations and actions. Now that tensions between Russia and the West are on the rise, while the threshold for military action and for neglecting international norms on part of Russia has significantly lowered, Georgia may again become a target of Russia's aggression along the lines of the proxy wars of the Cold War times.

Still, there is a strengthening sense of disappointment in European Union and the West in general (although the attitude has slightly improved lately)[17], that may grow especially after the most important symbolic act expected from the EU - the introduction of the visa-free regime for the Georgian citizens, has been once again postponed in early June this year, allegedly due to the Germany's demand. Equally disappointing in public eye is the never-ending process of joining NATO after such expectations have been created in the past.

This is developing parallel to ever-strengthening waves of Russian propaganda that on one hand attempts to discredit the EU showing it as a loosely united diverse region of degrading moral and uncertain future, experiencing grave economic problems and hit by numerous crises, too cautious in its actions and unable to take any decisive action; on the other hand, the benefits of aligning with Russia and joining Russian led Eurasian Economic Union are presented in unrealistically rosy colors, as opposed to the dangers and risks of distancing from Russia and becoming an American geopolitical puppet, that may be sacrificed and abandoned by the egotistic West at any moment as have happened in the past. Russia is also using its agents of influence to stir dissatisfaction with current state of affairs, the spread of traditionalist values and in particular - homophobia, xenophobia and ethnic and religious nationalism. This is also accompanied by the strengthening of Russian military presence and overall control over Georgia's breakaway territories of Abkhazia and South Ossetia, and significant reinforcement of the Russian military base in neighboring Armenia, in Gyumri.

Georgia is currently in a somewhat unusual situation unlike the past two decades, conditions here seem to be more stable and predictable than within its geopolitical environment [18] at least until the forthcoming parliamentary elections to take place in October 2016. Until now, the internal situation in Georgia seems to have somewhat stabilized, and whatever uncertainties and security threats can be envisaged in the short term, these did not seem to be of existential importance. Regarding the traditional external issues that may threaten Georgia's security, direct threat emanating from Russia seemed until recently to have been somewhat subdued, although it is difficult to say how things will develop after the annexation of Crimea and developments in Ukraine, and then in Syria, with Russian-Turkish tensions on the rise, while Georgia sandwiched between the two of them. If there is instability in the broader region, or for other reasons, Russia may decide to ignore the sovereignty of the Georgian state, especially if the process of Georgia's integration into NATO proceeds further. The key policy dilemma for Georgia is linked to its general and unwavering desire to integrate further into the European and Euro-Atlantic communities, and at the same time not to bring around dangerous hostility of Russia, which has much stronger interests in the Caucasus, more perseverance to act, no respect towards the international law, and more leverages than any other geopolitical actor in the region.

\section{Armenia}

In the case of Armenia, Russia is rather supportive of incumbent government, and its observers would always claim any rigged elections there as free and fair, whatever the evidence of the opposite. So, here Russian involvement is aimed at the preservation of status quo, rather than essentially changing anything, insofar as Armenian leadership remains loyal and obedient. As already mentioned, Armenia is fully dependent on Russia in guaranteeing its security, being squeezed between Azerbaijan and Turkey, with which it maintains uneasy relations after capturing Karabakh and the significant Azerbaijani territories around it. Russia is a member of the Minsk Group of mediators, and has made several demonstrative efforts at mediating solution over Karabakh and improving Armenian-Turkish relations, but there are many signs that it is perceived in Kremlin to be in Russia's national interest to maintain status quo along both of these dimensions, and thus preserving it strong leverage within the region. Russia maintains a strong military base in Armenia, with which it shares the membership in Collective Security Treaty Organization, and Russian troops are 
protecting Armenian borders with Turkey and Iran. Russia also fully controls Armenian energy sector, including the only nuclear power station in Metsamor, and the gas pipeline linking Armenia with Iran, along with many other economic assets. The most striking illustration of Russian hold on Armenian politics took place on September 3, 2013, when Armenian president Serge Sargsyan, after meeting Vladimir Putin in Moscow, in a highly humiliating move suddenly renounced his country's long advocated, by him personally, plan to sign the Association Agreement with EU, and promised instead to enter the Russian led Customs Union and at that time still non-existent Eurasian Economic Union. Although until recently it was difficult to find any influential anti-Russian and openly pro-Western politician in Armenia, still the Russian preference is to preserve the status quo and the fully controlled incumbent government, with all its authoritarian tendencies and corruption that makes it even easier to manipulate. However, lately more and more Armenians started questioning the sincerity of the Russian support of Armenia, especially in the light of it providing sophisticated weapons to Azerbaijan, and the frequently demonstrated general lack of respect towards Armenia's formal sovereignty. The recent springtime escalation of the situation around Karabakh in early April further strengthened suspicions and discontent among the Armenian public. [19]

In its turn, the EU experienced a serious setback with Armenian decision to skip the Association Agreement quite unexpectedly announced in September 2011 after the meeting of Sargsyan and Putin in Moscow, after all the work done. Although the educated layers of the Armenian society are very much pro-European in their cultural orientation, there is no freedom of maneuver for Armenia that would allow significant political influence of either EU or US on the developments there. However, if there is pro-democracy movement or a kind of 'color revolution' emerging in Armenia, along with the strengthening anti-Russian sentiment, there is no doubt that Russia has a number of powerful instruments to secure its interests and bring to power or preserve the most obedient and pro-Russian leadership[20]. At the same time, much will depend on what happens in Russia and its integrative projects, such as the Eurasian Economic Union, but even more so, on the fate of Russia's relation with the West, of which Armenia remains an unhappy hostage. In any case, the public attitude towards Russia is in general deteriorated, especially after crimes committed by the Russian soldiers on the Armenian soil, and as a result of Russia's contribution of the military build-up in Azerbaijan that became once again a strong irritant for the Armenian population after the recent flare-up of military action in and around Karbakh.

\section{Azerbaijan}

The case of Azerbaijan is a good illustration of the fact that the rich and the poor are treated differently, whether it is people or states. On one hand, the oil wealth of
Azerbaijan allowed it to secure public support by redistributing at least a part of this riches[21] on the other, it may allow itself to be less dependent on international assistance, and therefore, be more resistant to imposed change; finally, its huge resources and strategic importance allow Azerbaijan to achieve more tolerance on the part of western countries, and bribe its way through more corrupt individuals, institutions or countries (so called 'caviar diplomacy'). A sad illustration of this fact was the temporal coincidence of much publicized arrest of several leading human rights activists and journalists in the summer of 2014, at the same time as a conference took place in Washington, DC, supported by the Azerbaijani government, discussing the future of democracy in the region.[22] Recently some of the prominent political prisoners have been released under international pressure, but repressions still continue[23].As a result, the West has limited leverage over Azerbaijan, and its statements about strengthening authoritarianism, unfair election procedures, human rights abuses, or suppression of democratic freedoms often fall on a deaf ear. At the same time, Azerbaijan conducts active international policy of promoting its image, and spends significant funds on its PR campaigns in the west, but also participates in western-sponsored programs and initiatives. Until lately, Baku leadership and elites in general leaned towards the west, where they see a comfortable place to spend time, get education for their children, and invest oil revenues, but on their own conditions - the regime should not be threatened in any way. However, Russia still preserve significant leverages over Azerbaijani leadership, while at the same time it is fully tolerant towards any deviations from democratic practices there. While there were periods of temporary cooling of relations between Russia and Azerbaijan, leadership in Baku is well aware that Moscow holds much stronger sticks than the west could counterbalance with its weak carrots. One of the traditional instruments of Moscow's influence is Diasporas, and the Azeri diaspora in Russia is very significant, counting among others a few influential billionaires. Even stronger leverage is related to the Azerbaijan's ethnic minorities in the North and the South of the country, and finally Kremlin has many instruments to covertly destabilize a country, as clearly shown in Ukraine. Therefore, Baku leadership is cautious enough in its policies, and at present Moscow would also rather prefer to appease Baku, e.g. by selling it military hardware, or inviting into the Eurasian Economic Union, than risk alienation of this important player, or creating the need for employing more heavy-handed approaches.

\section{Prospects for the South Caucasus}

Recent political developments in the South Caucasus once again explicitly demonstrated the difficulties of post-Communist transition in the complex geopolitical environment. Formally existing democratic institutions may 
lead to formal or virtual (imitational or façade) democracy, even in absence of any communist or other coherent ideology. Although the state of affairs in one or another Caucasian state may sometimes be hailed for various reasons by some international democracy watchdogs, such external support may help bringing to power elites that are not necessarily democratic or effective, and that tend to slip soon to authoritarian practices or simply remain authoritarian. It should be kept in mind, however, that paths of authoritarianism in post-Soviet South only partially depend on such issues as external manipulation, affluence of resources ('resource curse'), confession, or ethnicity. Much more important are such factors as explicit pro-Western orientation of both elites and the population, existence of an educated urbanized middle class, and the tradition of successful political struggle.

Current situation in the region is characterized by high internal volatility and fragility of its institutions. The highest risk of regional instability remains to be linked to the potential of restarting the full-blown military action over Karabakh, even though neither Armenia nor Azerbaijan are eager to experience the implications of such a development. Equally unpredictable is the geopolitical environment in which the region finds itself, especially with dangerous developments unfolding both in the post-Soviet Space and in the Middle East. Russia has emerged as a still the strongest player in the region, and the player on one hand irrational, unpredictable and dangerous, on the other ready to defy any internal or international norms and laws when dealing with what it considers as national interests. Therefore, under current conditions the soft power of the West appears insufficient, as are the existing modest incentives of Euro-Atlantic integration or economic assistance, to promote democratic change and provide security, to counterbalance the direct hard threat of Russian expansionism and revanchism, or even its support of authoritarian regimes in its neighborhood.

The possible response to such prospects should be at least three-fold - on one hand increasing the incentives for democratic change, on the other - containing Russia's expansionism through sanctions and other means, and finally - through strengthening the ability (including military capability) of the countries of the region to withstand existing external threats. Counterbalancing influences and threats that lead to more authoritarianism, weakening of democratic institutions and sovereignty, and the very survival of the small South Caucasian states, is the challenge that the West may understand as important both for moral and the geopolitical reasons.

\section{REFERENCES}

[1] Alexander B. Downes, Jonathan Monten. "Forced to Be Free? Why Foreign-Imposed Regime Change Rarely Leads to Democratization.” International Security, Spring 2013, Vol.
37, No. 4, Pages 90-131; Will Kymlicka, Magda Opalski (eds.) Can liberal pluralism be exported? Oxford University Press, 2002

[2] Jørgen Møller. Post-communist Regime Change: A Comparative study. Routledge, 2009; Lucan Way. Pluralism by Default: Weak Autocrats and the Rise of Competitive Politics. Johns Hopkins University Press, 2015

[3] Jülide Karakoç (ed.) Authoritarianism in the Middle East: Before and After the Arab Uprisings. Palgrave Macmillan, 2015

[4] See, e.g. Lilia Shevtsova. "Putin Doctrine: myth, provocation, blackmail, or the real deal?" http://www.the-american-interest.com\%2Farticles\%2F2014 $\% 2 \mathrm{~F} 04 \% 2 \mathrm{~F} 14 \% 2 \mathrm{Fthe}$-putin-doctrine-myth-provocation-blac kmail-or-the-real-deal\%2F\&h=uAQEPzA3v; Игорь Зевелев. Новая внешнеполитическая доктрина России. Ведомости 4/8/2014http://www.vedomosti.ru/opinion/news /24981841/novaya-vneshnyaya-politika-rossii?full\#cut

[5] Rachel Vanderhill. Promoting Authoritarianism Abroad. Boulder, Colorado, 2013; Rachel Vanderhill. "Learning to Be Bad: How Autocratic Leaders Adopt Strategies from Abroad to Maintain Power". APSA Annual Meeting Paper, 2012.

http://papers.ssrn.com/sol3/papers.cfm?abstract_id=2108791; Gero Erdmann, André Bank, Bert Hoffmann, and Thomas Richter. International Cooperation of Authoritarian Regimes: Toward a Conceptual Framework. GIGA Working Paper, No 229, July 2013. http://www.giga-hamburg.de/de/s ystem/files/publications/wp229_erdmann-bank-hoffmann-ric hter.pdf

[6] Peter Burnell. "Promoting Democracy \& Promoting Autocracy: Towards a Comparative Evaluation". Journal of Politics and Law, Vol. 2, \#2, 2010. pp. 3-14 http://citeseerx.ist.psu.edu/viewdoc/download?doi=10.1.1.67 $8.9850 \&$ rep $=$ rep $1 \&$ type $=$ pdf

[7] Steven Levitsky, Lucan A. Way. 2002. "The Rise of Competitive Authoritarianism“. J. of Democracy 13 (2), 51-65. Also available online at http://scholar.harvard.edu/lev itsky/files/SL_elections.pdf; S. Levitsky, L. Way. 2010. Competitive Authoritarianism: international linkage, organizational power, and the fate of hybrid regimes. New York: Cambridge University Press.

[8] Jonathan Wheatley, Christoph Zürcher. 2008." On the Origin and Consolidation of Hybrid Regimes: The State of Democracy in the Caucasus". Taiwan Journal of Democracy, Volume 4, No.1, pp. 1-31. Available online athttp://www.tfd.org.tw/docs/dj0401/001-032-Jonathan\%20 Wheatley.pdf

[9] Dmitri Furman. 2008. „Imitation Democracies“. New Left Review \#54, November-December. Also available online at http://www.newleftreview.org/?view=2750

[10] See, e.g.: Eric Neumayer, Thomas Plümper. 2010. “Galton's Problem and Contagion in International Terrorism along Civilizational Lines". Conflict Management and Peace Science, Vol. 27, No. 4, pp. 308-325. http://papers.ssrn.com/ sol3/papers.cfm?abstract_id $=1347949$

[11] G. Tarkhan-Mouravi. Brief History of Georgia in: "Eastern Europe, Russia and Central Asia" encyclopaedia (ed. Dominic Heaney). Routledge/Taylor \& Francis Group: London. 2015 
[12] Charles King. 2001. "Potemkin Democracy: Four Myths of Post-Soviet Georgia". The National Interest, June 1. Available online at http://nationalinterest.org/article/potemki n-democracy-958

[13] Lincoln A. Mitchell, Valerie Bunce, Charles King, Lorne Craner, Chris Walker. 2009. Georgia's Uncertain Democracy. Panel discussion at Columbia University, March 26. Summary available online athttp://www.siwps.co $\mathrm{m} /$ events.attachment/mitchell/Mitchell.pdf

[14] Lincoln A. Mitchell. 2012. „The Impact of Speaking Publicly About Democracy in Georgia“", Foreign Policy, April 8. Available online at http://www.thefastertimes.com/f oreignpolicy/2012/04/08/the-impact-of-speaking-publicly-ab out-democracy-in-georgia/

[15] Paul Goble. "Kremlin Think Tank Confirms Close Links with Kremlin and with New Greek Premier". The Interpreter, February 15, 2015. http:/www.interpretermag.com/kremlinthink-tank-confirms-close-links-with-kremlin-and-with-newgreek-premier/

[16] See, e.g.: Чернов М.И. Осетия: рождение большой мечты. Российский институт стратегических исследований. Москва, 2013 (M.I. Chernov. Ossetia: the birth of a great dream. RISI, Moscow, 2013)

[17] Results of March 2016 Public Opinion Poll in Georgia. NDI, Tbilisi, April 2016 https://www.ndi.org/georgia-polls
[18] Thomas de Waal. "Stormy Weather in the Caucasus". Eurasia Outlook, January 8, 2014. http://carnegie.ru/eurasiao utlook $/$ fa $=54118$

[19] Maciej Falkowski. "Apathy to nationalist mobilization: politics makes a comeback in Armenia". OSW Commentary, June 29, 2016 http://www.osw.waw.pl/en/publ ikacje/osw-commentary/2016-06-29/apathy-to-nationalist-m obilisation-politics-makes-a-comeback

[20] Emil Danielyan. "Why Armenia's Military Alliance with Russia Is Not at Risk". RFE/RL, November 07, 2015 http://www.rferl.org/content/caucasus-report-armenian-russi a-military-alliance/27351046.html

[21] Benjamin Smith. "The wrong kind of crisis: Why oil booms and busts rarely lead to authoritarian breakdown". Studies in Comparative International Development, Winter 2006, Vol. 40, Issue 4, pp 55-76. http://link.springer.com/article/10.100 7\%2FBF02686303\#page-1

[22] "Leading Azerbaijani Rights Defender Arrested as US Officials Attend Regime's PR Convention in DC". Azeri Report, June 4, 2014. http://azerireport.com/index2.php?opti on $=$ com_content\&do_pdf $=1 \& \mathrm{id}=4306$

[23] Samira Ahmedbeyli. "Azerbaijan: Political Arrests Continue”. IWPR, June 4, 2016. https://iwpr.net/global-voic es/azerbaijan-political-arrests-continue 